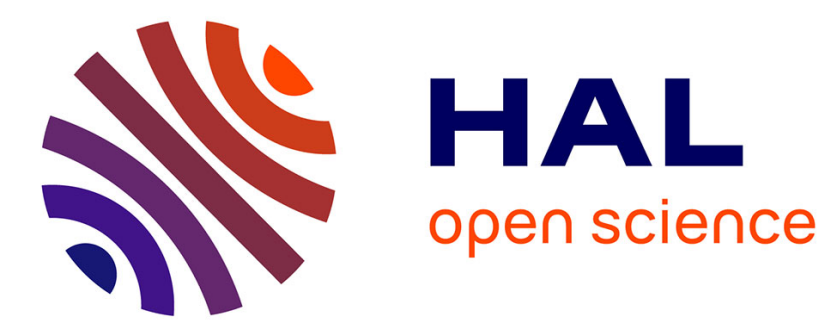

\title{
The influence of rearing and lay risk factors on propensity for feather damage in laying hens
}

Kelly Drake, Christl Donnelly, Marian Stamp Dawkins

\section{To cite this version:}

Kelly Drake, Christl Donnelly, Marian Stamp Dawkins. The influence of rearing and lay risk factors on propensity for feather damage in laying hens. British Poultry Science, 2010, 51 (06), pp.725-733. 10.1080/00071668.2010.528751 . hal-00652141

\section{HAL Id: hal-00652141 \\ https://hal.science/hal-00652141}

Submitted on 15 Dec 2011

HAL is a multi-disciplinary open access archive for the deposit and dissemination of scientific research documents, whether they are published or not. The documents may come from teaching and research institutions in France or abroad, or from public or private research centers.
L'archive ouverte pluridisciplinaire HAL, est destinée au dépôt et à la diffusion de documents scientifiques de niveau recherche, publiés ou non, émanant des établissements d'enseignement et de recherche français ou étrangers, des laboratoires publics ou privés. 


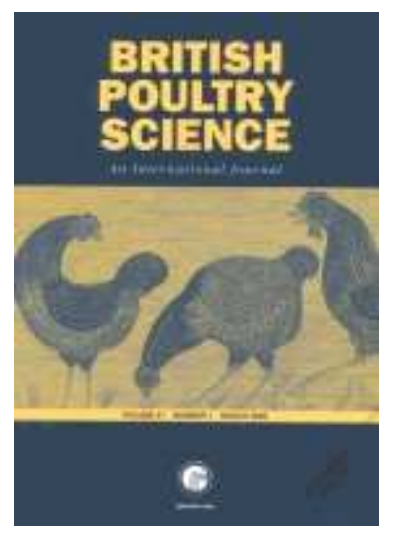

\section{The influence of rearing and lay risk factors on propensity for feather damage in laying hens}

\begin{tabular}{|c|c|}
\hline Journal: & British Poultry Science \\
\hline Manuscript ID: & CBPS-2009-342.R1 \\
\hline Manuscript Type: & Original Manuscript \\
\hline $\begin{array}{r}\text { Date Submitted by the } \\
\text { Author: }\end{array}$ & 14-Feb-2010 \\
\hline Complete List of Authors: & $\begin{array}{l}\text { Drake, Kelly; Oxford University, Zoology } \\
\text { Donnelly, Christl; Imperial College London, M.R.C. Centre for } \\
\text { Outbreak Analysis and ModellingDepartment of Infectious Disease } \\
\text { Epidemiology } \\
\text { Dawkins, Marian; Oxford University, Zoology }\end{array}$ \\
\hline Keywords: & Feather pecking, Feathers, Welfare \\
\hline
\end{tabular}

\section{SCHOLARONE \\ Manuscripts}


Note to P. Lewis. A few general formatting points. Some phrases in bold, some et al.s not in italics.

2 The first para of "Statisitical analysis" contains several 'levels' - I try to encourage authors to avoid the

3 word - it's lazy and sometimes ambiguous - wherever possible it should be replaced by the actual

4 measure - concentration, intensity, number etc and sometimes it can even be deleted altogether. Think

5 about its use here. Some probability symbols are lower-case Roman. Ampersands in some text

6 references.

8 Influence of rearing and lay risk factors on propensity for feather damage in

9 laying hens

10

11 K. A. DRAKE, C. A. DONNELLY ${ }^{1}$ AND M. STAMP DAWKINS

12

13 Department of Zoology, University of Oxford and ${ }^{1}$ M.R.C. Centre for Outbreak

14 Analysis and Modelling, Department of Infectious Disease Epidemiology, Imperial

15 College, London, England

16

17 Short title: Feather damage in laying hens

Correspondence to Prof. Marian Stamp Dawkins. Department of Zoology, University

21 of Oxford, South Parks Road, Oxford OX1 3PS, U.K.

22 Phone: $+44(0) 1865271215$

23 Fax: +44(0) 1865310447

24 Email: marian.dawkins@ zoo.ox.ac.uk

26 Accepted for publication 10 July 2010 


\section{Abstract.}

1. Feather pecking is one of the major problems facing the egg industry in noncage systems and is set to become even more of an issue with the European Union ban on the keeping of laying hens in barren battery cages which comes into force in 2012 and a UK ban on beak-trimming in 2011. Reducing feather pecking without resorting to beak treatment is an important goal for the poultry industry.

2. We report here a longitudinal study that included over 335500 birds from 22 free range and organic laying farms. Accelerated failure time models and proportional hazards models were used to examine the effects of a wide range of factors (management, environment and bird) on development of substantial feather damage in lay. Particular emphasis was placed on risk factors during rear and on practices that could feasibly be changed or implemented.

3. The age at which a flock exhibits substantial feather damage could be predicted both by factors in the environment and by early symptoms in the birds themselves. Factors that were associated with earlier onset of severe feather damage included the presence of chain feeders, raised levels of carbon dioxide and ammonia, higher sound and light levels, particularly in younger birds. Increased feather damage (even very slight) in birds at 17-20 weeks of age was also highly predictive of the time of onset of severe feather damage during lay. Increased feed intake also indicated that a flock was at risk of early severe feather damage.

4. Birds that stayed on the same farm for rearing and lay showed later onset of serious feather damage than those that experienced a change in farm from rearing to lay. However, an increased number of changes between rearing and 
53 lay (feeder type, drinker type, light intensity etc) was not associated with 54 earlier onset of serious feather damage. Further research needs to be done on 55 the role of the transition from rearing to lay as a risk factor for FP in lay. 
58 A major welfare problem in the commercial egg production industry is that of

59 injurious feather pecking (FP) in laying hens (Savory, 1995; Green et al., 2000;

60 Bright, 2009; Bestman et al., 2009). Injurious FP leads to increased feed

61 consumption due to heat loss (Tauson and Svensson, 1980), a reduction in egg

62 production (El-Lethey et al., 2000), pain and suffering of the injured birds (Gentle and

63 Hunter, 1991) and increased bird mortality, including cannibalism (Huber-Eicher and

64 Sebo, 2001).

In 2012, barren cages will be banned in the European Union in line with Directive 1999/74/EU. This will increase the number of birds kept in non-cage laying systems (barn, colony, free range and organic), which in turn will increase the numbers of birds at risk of injurious FP and cannibalism (Blokhuis et al., 2007; Fossum et al, 2009). Beak treatments that blunt the beak and so reduce the impact of

71 of controlling FP, but raise welfare issues in their own right (Gentle et al., 1990;

72 Hughes and Gentle, 1995). Furthermore, beak treatments of all types will be

73 banned in the UK from 2011. There is therefore an urgent need to find ways of

74 controlling FP without resorting to beak treatment.

Despite the much greater understanding of the factors predisposing hens to 77 still not possible (Rodenburg et al., 2004; Dixon, 2008). The problem is multi78 factorial and stems from interactions between the bird, the environment and 79 management variables in ways that are not yet understood (Rodenburg et al., 2008a).

80 Environmental factors experienced by birds during rearing have been identified as 81 particularly important to the development of later FP in adult flocks (Johnsen et al., 
82 1998; Gunnarsson et al., 1999; van der Weerd, 2006, Staack et al, 2007; Riber et al, 83 2007; Rodenburg, et al., 2008b) but it is not clear whether particular factors are 84 critical or whether it is the change between rearing and lay factors that is most important. However, even if it is not currently possible to prevent FP altogether, it would greatly help producers if they were able to predict outbreaks of FP before they occur or at least detect them at the onset. This would allow action to be taken before the welfare and production of the birds was adversely affected and to concentrate such measures on high risk flocks.

The aim of this longitudinal study was to identify factors (bird, management and environment) in the early environments of laying hens in commercial non-cage systems that predict which flocks are at the greatest risk of developing FP later in lay. Commercial flocks were followed from rear throughout the laying period until clearance and we collected data on a variety of factors about the birds themselves (strain, feather cover, feed intake) as well as the environments they were in. We looked for signs in young flocks that might indicate they were at high risk of developing FP later in life and also at factors in the rearing and laying environments that might be associated with severe feather damage. We examined both the role of particular factors in the rearing environment that might predispose an adult flock to feather damage and also the role of changes between the rearing and the laying environment that might constitute a particularly high risk.

\section{MATERIALS AND METHODS}

Approximately 335000 commercially reared laying hens were followed from 12 rearing farms on to 19 laying farms between February 2006 and August 2008. The laying farms consisted of 44 houses, the majority of which were internally subdivided into colonies (birds physically separated by a barrier but within the same 
107 house). This gave a total of 84 colonies, where a colony could be either a whole 108 house (no internal barriers between flocks) or a single undivided house. A single 109 colony could contain between 780-4000 birds. As colonies within a house were not 110 fully independent, data were analysed statistically with house $(n=44)$ as the 111 independent unit.

112 The study included three different types of laying systems: barn (2 houses/10 113 colonies), organic free-range (19 houses/19 colonies) and free-range systems (42 114 houses/55 colonies). Flocks were comprised of 5 laying bird hybrids: Hyline, 115 Lohmann (Brown and Traditional), Shaver, Bovans Goldline, Columbian Black Tail 116 and a mix of Hyline and Goldline. Birds from 18 out of the 19 farms were beak-

117 treated at 5-7 d old. One farm which did not beak-treat initially, had to beak treat two 118 colonies at 30 weeks of age. Another farm had to repeat the beak-treatment for 4 119 colonies at 35 weeks of age. The methods used for beak treatment were; infra-red (4 120 houses) and traditional hot-blade (40 houses). Each house was visited on at least 4 121 occasions; towards the end of rear $(<17$ weeks), after transfer to the lay house $(\sim 18-$ 12222 weeks), peak-lay ( 23-30 weeks) and close to clearance ( 50 wks). Additional 123 visits were made to some farms to establish a more thorough database of events. Due 124 to insufficient numbers in the barn systems and houses using infra-red beak 125 treatments, we were unable to meaningfully compare the impact of these 126 variables on propensity for feather damage.

\section{Feather damage}

128 Feather damage scores were recorded during each visit for each colony both inside the 129 house and from birds on the corresponding range outside the house by visual 130 inspection using the method described by Bright et al. (2006); 100 birds were visually 131 assessed for feather damage (Table 1) from each colony and 100 from each range 
132 outside the house. A random number grid map was used to select the birds. Five

133 different body regions on the bird were selected (neck, back, rump, tail and wing) and

134 scored on a best (0) to worst (4) scale (Table 1). Feather damage scores were

135 collected during each visit and averaged to give a mean feather damage score for each

136 body region and an average total (that is,. summed) feather score for each colony. We

137 considered mean feather damage greater than or equal to the threshold of 3.8 (at any

138 age) to be substantial feather damage in an attempt to 'predict' whether a flock was at 139 risk of becoming a 'feather pecking flock'.

140 Management and husbandry

141 The first visit was conducted at the rearing house (12 - 17 weeks of age). This visit

142 gathered detailed information on general management, husbandry practices and the

143 bird. The following were recorded: season of rear and hatch month, size of farm

144 (number of houses, numbers and ages of birds currently on farm, strain of bird,

145 age of parent flock, flock size, stocking density, drinker type (bell, bell and

146 nipple, nipple, nipple with cup), number of drinkers per house, feeder type

147 (chain, chain and pan, pan), number of feeders per house, litter type (cut straw,

148 newspaper, woodchip), lighting source/number (fluorescent, tungsten, daylight,

149 redlight or combination, enrichments such as perches, bales etc. Birds were

150 transferred to the laying houses between $17-18$ weeks. A record was kept of

151 whether the laying houses were on the same or a different farm. The first visit to the

152 laying farm (between 18 and 22 weeks of age) consisted of recording the

153 management, husbandry practices, bird, environment and production variables listed

154 above and in addition recording details of the laying system (barn, free-range,

155 organic), other species on farm, age at transfer, verandas (Y/N) \% of house floor

156 slatted or litter, range size, \% range area covered by vegetation, vegetation type 
157 (no trees, artificial shelter, small growing trees, mature growing trees, mature

158 trees with artificial shelter).

\section{Environmental variables}

160 Environmental variables were measured during each visit. Within each colony, 4

161 locations were chosen randomly using a grid map, two in the slatted area and

162 two on litter. Environmental measures were taken at all 4 locations and the mean of

163 these calculated for each colony. The measures taken were: sound (dB) intensity

164 (using a Sound level meter ST-8850, Farnell in One, Leeds, UK), lux (using a TES

165 1330A Digital Lux meter, York Survey Supply Centre, York, UK), litter pH and

166 temperature (using a HI-991300 pH/Temperature meter, Hanna Instruments, Bedford,

167 UK) and ammonia and carbon dioxide gas concentrations (5-100 ppm and 300-5000

168 ppm respectively) (using RAE gas detection tubes, RAE Systems Inc., California,

169 USA and a Gastec GV-100S pump, Gastec Corporation, Japan) were recorded. All

170 variables were recorded at bird height $(\sim 30 \mathrm{~cm}$ from ground).

171 Production variables

172 Weekly production records were collected by the producers and included percent of

173 birds in lay, percent mortality and feed consumed (gram/hen/d). Production records

174 that were not directly supplied varied from farm to farm, and not all farms collected

175 the same information; however all recorded those listed above.

176 Statistical analysis

177 The independent unit for analysis was the house $(n=44)$. The aim of the analysis was

178 to identify which factors contributed to the risk of 'failure', that is a given flock

179 yielding a mean feather damage score of $\geq 3.8$. Although any arbitrary level of feather

180 damage could be defined as 'failure', 3.8 represents a substantial level when feathers

181 are severely damaged and/or areas of naked skin are visible (Table 1). This is the level 
182 of damage seen in approximately half of all flocks before 40 weeks of age, with some

183 flocks reaching this level earlier and some never (Figure 2). The choice of this

184 threshold gives the model better predictive power than by choosing a threshold that 185 was always met or never met.

186 The aim of our analysis was to describe associations between the time at

187 which a flock experiences failure (mean feather damage score of $\geq 3.8$ ) and 188 characteristics of the farm, house and flock. If every flock had been observed to 189 fail (in other words there were no censored data), then regression would be an 190 obvious choice for describing relationships between predictors and the time at 191 which each flock experienced failure. In our study, however, many flocks were 192 never observed to fail. Thus, our analyses needed to allow for censoring. We 193 performed two parallel sets of such analyses, based on accelerated failure time 194 models and Cox proportional hazards models, each indicating whether or not 195 (and to what extent) the variable in question had a significant effect on 'failure' 196 times of flocks. Accelerated failure time models (Wei, 1992) produce estimates of 197 differences (in weeks) in the time to failure associated with different potential 198 predictors (such as with or without transfer to a different farm between rear and 199 lay) by regressing the logarithm of the survival time over the covariates, while 200 allowing for censored data. In contrast, Cox proportional hazards models (Cox, 201 1972) produce estimates of relative hazards (risk of failure), under the 202 assumption that the impact of a predictor is multiplicative. In other words, a 203 factor that halves risk for a relatively low-risk flock will also halve risk for a 204 relatively high-risk flock. The results of the two methods were highly consistent. 205 We report the results of the accelerated failure time models here because the 206 results are in terms of absolute differences (in weeks) in times to failure and therefore 
207 have immediate biological meaning. The results are given as the estimated $\%$

208 reduction (or increase) in the age at which flocks showed a mean feather score of 3.8

209 or more, together with $95 \%$ confidence limits for the $\%$ reduction (or increase) and its

210 associated $P$-value.

\section{RESULTS}

213 Descriptive results of feather pecking

214 Figure 1 shows initial bird numbers on transfer into the lay houses $(n=44)$, final bird

215 number at depletion (mark on bar) and houses which ones developed FP prior to 40

216 weeks of age (asterisk). There was large variability of number of houses on farms and 217 numbers of birds housed across, and within farms.

\section{Feather scores}

219 Figure 2 shows the incidence of feather damage in flocks of different ages for all 220 colonies $(n=84)$ observed in the study. Feather damage increased with age and was 221 cumulative but $23 \%$ of houses never reached the FP threshold of 3.8. Within houses, 22216 out of 84 colonies $(19 \%)$ reached the threshold of $\geq 3.8$ by 40 weeks of age, 29 223 colonies (35\%) by 41-50 weeks of age and by 60 weeks of age, 49 colonies (59\%) had 224 reached the feather damage threshold.

225 Table $\mathbf{2}$ shows that the feather damage score at a given age predicted the time 226 in the future when a flock would reach the FP threshold. (A unit = an increase of 1.0 227 in the average total feather score as defined in Table 1). Particularly notable is the fact 228 that predictions could be made even by observing young birds less than 20 week of 229 age, where there was relatively little feather damage (Figure 2). The feather damage 230 scores for birds 17-20 weeks ranged between 0.03-1.18. Nevertheless, the feather 
231 damage score measured at this time were highly predictive of the age at which a

232 house would later cross the threshold feather score of $\geq 3.8$ (Table 2).

233 Management and husbandry

234 The effect of various management systems and husbandry practices are shown in 235 Table 3. Chain feeders were significantly associated with earlier failure times than 236 pan feeders. Low feeders (those on the ground) were associated with earlier onset of 237 FP than High (raised above the ground). Pan feeders were always raised above 238 ground level.

\section{Production}

240 Neither $\%$ mortality in the flock nor the $\%$ of birds in lay was predictive of when that 241 flock would reach a FS of $\geq 3.8$ (for mortality $\mathrm{p}>0.1$ at all ages; for $\%$ birds in lay $242 \mathrm{p}>0.5$ at all ages). However, the mean amount of feed eaten (g/day per individual) 243 was significantly predictive, at least when birds were less than 17 weeks and between 24420 and 24 weeks of age, indicating that the more feed that was eaten, the earlier 245 failure time occurred (Table 4).

\section{Environmental variables}

247 The levels of the environmental variables recorded (carbon dioxide $\left(\mathrm{CO}_{2}\right)$, ammonia $248\left(\mathrm{NH}_{3}\right)$, light (lux), noise $(\mathrm{dB})$, litter $\mathrm{pH}$ and temperature $\left({ }^{0} \mathrm{C}\right)$ are shown in Table 5.

249 In laying houses, higher $\mathrm{CO}_{2}$ levels were associated with earlier onset of FP: 250 between 24 and 30 weeks of age, each $200 \mathrm{ppm}$ increase in $\mathrm{CO}_{2}$ was associated 251 with a $\mathbf{1 4 . 8 \%}$ reduction in time to failure $(95 \%$ confidence interval $\mathbf{- 1 9 . 7 \%}$ - $2529.5 \% ; p=0.0001)$. Higher ammonia levels were also associated with earlier onset 253 of $\mathrm{FP}$ : every $15 \mathrm{ppm}$ increase in $\mathrm{NH}_{3}$ recorded between the ages of 15 and 17 254 weeks was associated with a $\mathbf{1 0 . 1 \%}$ reduction in time to failure (CI $\mathbf{- 1 6 . 2 \%}$ - - 
$2553.5 \%$; $=0.003$ ); between the ages of 24 and 30 weeks, it was associated with a

$256 \quad \mathbf{1 2 . 9 \%}$ reduction in time to failure (CI: $-18.7 \%-\mathbf{- 6 . 8 \%} ; \mathrm{p}=\mathbf{0 . 0 0 0 1})$.

257 Light was another risk factor, particularly if light levels were high in 258 young birds. Higher light levels in birds of 17-20 weeks were associated with an 259 earlier onset of FP: each 100 lux increase was associated with a $12.2 \%$ reduction 260 in time to failure (C.I.: $\mathbf{- 1 8 . 9 \%}-\mathbf{- 3 . 9 \%} ; \mathbf{p = 0 . 0 0 3 4})$. The final factor we found to 261 be associated with earlier onset of FP was sound level. Between 15 and 17 weeks, 262 each $10 \mathrm{~dB}$ increase in sound was associated with $25.5 \%$ reduction in time to 263 failure (C.I.= -39.6\% - -8.2\%; p=0.0056) and between 17-20 weeks, with a 7.9\% 264 reduction in time to failure (C.I.= $\mathbf{- 1 3 . 5 \%}-\mathbf{- 2 . 0 \%} ; \mathbf{p = 0 . 0 0 9 9})$. No significant 265 differences were found at any age category for either litter $\mathrm{pH}(\mathrm{p}>0.3)$ or for 266 temperature $(\mathrm{p}>0.05)$ measured during the visit.

267 Environmental factors during rearing

268 Factors in rearing that influenced FP later in lay are shown in Table 6. The type of 269 feeders and drinkers had a significant effect on age at which FP developed. FP 270 developed earlier in flocks that came from rearing houses with chain feeders than 271 from those with pan feeders or a combination of feeder types. FP developed earlier in 272 laying flocks that had been reared in houses with a bell and nipple drinker system than 273 those with nipples only, or nipple/cup systems.

\section{Changes from rearing to laying environment}

275 Table 7 shows the effects of changes from the rearing environment to the laying 276 environment. Where the feeder system did not change from rear to lay, FP was found 277 to start sooner than when the feeder system changed between farms (Table 7). 278 However, it should be noted that the only recorded instances of where the feeder 279 system was the same in rear and in lay were those in which there was a chain feeder in 
280 both. Chain feeders appear to be a risk factor in themselves (Table 6). An earlier start 281 to FP occurred earlier in lay with birds that were moved to a different farm (Table 7).

To obtain an idea of whether FP was affected by the number of changes 283 between rearing and lay, we added together the effects of all recorded changes 284 (veranda, perches, feeder type, drinker type, lighting, transfer to a different lay farm). 285 This is shown as 'sum' in the bottom row of Table 7 and was not associated with an 286 earlier risk of feather damage.

Birds hatched as chicks in July-March showed a delay in reaching the feather score of $\geq 3.8$ of $17.2 \%$ compared to birds hatched in April, May or June (2.9-33.5\%, p $=0.0169$ ) indicating FP started earlier for those hatched April-June.

DISCUSSION

Our results show that the age at which a flock exhibits substantial feather damage can be predicted both by factors in the environment and by early symptoms in the birds themselves. Environmental actors that were associated with earlier onset of severe feather damage included the presence of chain 295 feeders, raised levels of carbon dioxide and ammonia, higher sound and light levels, particularly in younger birds.

Our results also show that it is possible to predict which flocks are at greatest 298 risk of feather pecking before serious feather damage is apparent. Even in young birds 299 (under 20 weeks of age), when very little feather damage is seen in any flocks, slight 300 differences in feather score are predictive of the level of feather damage at later ages 301 (Table 2). In other words, even slightly raised feather scores in young birds are 302 associated with earlier onset of serious feather damage, supporting similar studies by 303 Bright (2009) and Bestman et al. (2009). This means that just by looking at a 
304 young laying flock, it may be possible to predict how likely they are to develop

305 serious feather damage.

Another factor that is suggestive of future problems is feed intake. Flocks that showed early signs of increased daily feed intake were also likely to show earlier severe feather damage (Table 4). However, this was only shown to be significant between $20-24$ weeks of age. This is of interest as it is known that birds increase their feed consumption due to heat loss, if, severely feather pecked (Tauson and Svensson, 1980). Therefore, the first signs of an increase in food consumption may indicate a measure in which to 'predict' a problem before it becomes an issue of welfare or productivity.

While our results are consistent with the previous studies that have emphasized the factors in the rearing environment that influence feather pecking in later life (Blokhuis \& van den Haar, 1989, 1992; Norgaard-Nielsen et al., 1993; Johnsen et al, 1998; Newberry et al,, 2007), we have here attempted to separate the influence of factors in the rearing environment per se from the influence of changes between rearing and laying environments. For example, factors such as light levels in rearing might appear to have little effect on likelihood of feather damage in lay (Kjaer \& Sorenson 2002), but a change in light level as the birds were moved from rear to lay might have a much bigger effect. We therefore asked separate questions about the factors in rearing that were associated with later feather pecking and about whether or not birds had experienced a change in those factors as they were moved from rearing to laying houses.

The accelerated failure time models used in this study point to a number of factors in rearing that are associated with earlier onset of serious feather damage. 
329 Factors associated with such a risk include feeder type and position, with chain 330 feeders associated with earlier failure (Table 6). It is not clear why chain feeders 331 appear to pose a risk.. Freire et al. (1999) found that, in modified cages, increased 332 feather pecking was associated with lower feed troughs (6 cm above ground) 333 compared to $28 \mathrm{~cm}$.. They suggested that this was because hens stepped on each 334 other, leading to feather damage and subsequent FP. The possibilities that low 335 feeders may hamper movement of an attacked bird, lead to feather damage or 336 that they are associated with more restricted feeding would be well worth further 337 investigation. Although our data are suggestive rather than conclusive, a lack of a 338 veranda for young birds during rearing may also be associated with earlier risk of 339 feather pecking. (The value of providing verandas for young birds could usefully be 340 explored). Among environmental factors, poor air quality (levels of $\mathrm{CO}_{2}$ and 341 ammonia) and higher light levels predispose flocks to develop feather pecking at an 342 earlier age (Table 6).

343 In addition, increased sound levels within a house (up to 20 weeks of age) 344 were associated with an early propensity to feather peck. However, as in a study by 345 Bright (2008), it is not clear whether the observed effects were due to noise made by 346 the birds themselves (birds that vocalise a lot have a tendency to FP) or due to 347 environmental noise increasing the tendency to FP. Either way, the role of sound 348 deserves more attention in future (Bright, 2008). It could either be a useful indicator 349 that a given flock is 'at risk' of developing FP or a pointer to the relatively easy 350 intervention of reducing noise levels to reduce risk of FP.

351 We then examined the effects of change between rear and lay. One factor 352 that seemed to be of considerable importance was whether birds moved farms 353 between rear and lay. Although the numbers reported here are small, there is a strong 
354 suggestion that staying on the same farm may postpone the risk of feather pecking in

355 lay (Table 7). This might be because birds staying on the same farm do not 356 experience a long journey or it could be that where rearing and laying houses are on 357 the same farm, they are more likely to provide more similar conditions than if they are 358 on different farms. We attempted to test the idea that 'amount of change' in 359 environmental conditions was important by looking at the effects of the number of 360 changes between rear and lay. We failed to detect any additive effect of the number 361 of changes (Table 9). Nevertheless, we suggest that further studies of the transition 362 between rearing and laying environments could be very valuable. Keeping birds on 363 the same farm throughout their lives is not usually possible, but more attention to the 364 differences they experience as they move from rear to lay might suggest ways of 365 reducing the chances of severe feather damage later on.

366 In conclusion, it is possible to predict which flocks are at risk of FP before 367 serious feather damage has occurred later in lay. Given the multifactorial nature of 368 FP and the difficulties of eliminating it altogether, the ability to identify 'at risk' 369 flocks could still be of value to producers since it could enable them to target 370 preventive action specifically on the flocks most at risk. Future research aimed at 371 reducing the risk of feather pecking could profitably concentrate on the role of feeder 372 layout, air quality, and light and sound levels, as well as the role of changes between 373 rearing and laying environments.

\section{Acknowledgements}

375 We thank DEFRA for funding this research (Contract no. AW 1134), and also thank 376 Noble Foods Ltd, Stonegate and farmers for providing facilities which we were 377 permitted to visit. 
378

379

380

381

382

383

384

385

386

387

388

389

390

391

392

393

394

395

396

397

398

399

400

401

\section{References}

BESTMAN, M., KOENE, P. \& WAGENAAR, J.-P. (2009) Influence of farm factors on the occurrence of feather pecking in organic reared hens and their predictability for feather pecking in the laying period. Applied Animal Behaviour Science, 121: 120-125.

BLOKHUIS, H.J., VAN NIEKERK, T.F., BESSEI, W. et al (2007) The LayWel project: welfare implications of changes in production systems for laying hens. World's Poultry Science Journal, 63: 101-114.

BRIGHT, A., JONES, T.A. \& DAWKINS, M.S. (2006) A non-intrusive method of assessing plumage condition in commercial flocks of laying hens. Animal Welfare 15: 113-118.

BRIGHT, A. (2008) Vocalisations and acoustic parameters of flock noise from feather pecking and non-feather pecking laying flocks. British Poultry Science, 49: 241-249.

BRIGHT, A. (2009) Time course of plumage damage in commercial layers. Veterinary Record, 164: 334-335.

DENNIS, R.L., FAHEY, A.G. \& CHENG, H.W. (2009) Infrared beak treatment method compared with conventional hot-blade trimming in laying hens. Poultry Science, 88: $38-43$.

DIXON, G. \& NICOL, C.J. (2008) The effect of diet change on the behaviour of layer pullets. Animal Welfare, 17: 101-109.

DIXON, L.M. (2008) Feather pecking behaviour and associated welfare issues in laying hens. Avian Biology Research, 1:73-87 
402 EL-LETHEY,H., AERNI, V., JUNGI, T.W. \& WACHSLER, B. (2000) Stress and 403 feather pecking in laying hens in relation to housing conditions. British $404 \quad$ Poultry Science, 41: 22-28.

405 FOSSUM, O., JANSSEN, D.S., ETTERLIN, P.E. et al (2009) Causes of mortality in 406 laying hens in different housing systems in 2001 to 2004. Acta Veterinaria 407 Scandinavica, 51. Art No. 3 Jan 15.

408 FREIRE, R., WALKER, A., \& NICOL, C.J. (1999) The relation between trough 409 height, feather cover and behaviour of laying hens in modified cages. Applied $410 \quad$ Animal Behaviour Science, 63: 55-64.

411 GENTLE, M.J., WADDINGTON, D., HUNTER, L.N. \& JONES, R.B. (1990) 412 Behavioral evidence for persistent pain following partial beak amputation in 413 chickens. Applied Animal Behaviour Science, 27:149-157.

414 GENTLE, M.J. \& HUNTER, L.N. (1991) Physiological and behavioural responses 415 associated with feather removal in Gallus gallus var. domesticus. Research 416 Veterinary Science, 50: 95-101.

417 GREEN, L.E., LEWIS, K. \& NICOL, C.J. (2000) Cross-sectional study of the 418 prevalence of feather pecking in hens in alternative systems and its 419 associations with management and disease. Veterinary Record 147: 233-238.

420 GUNNARSSON, S., KEELING, L.J. \& SVEDBERG, J. (1999) Effect of rearing 421 factors on the prevalence of floor eggs, cloacal cannibalism and feather 422 pecking in commercial flocks of loose housed laying hens. British Poultry $423 \quad$ Science, $40: 12-18$.

424 HUBER-EICHER, B. \& SEBO, F. (2001) Reducing feather-pecking when raising 425 laying hen chicks in aviary systems. Applied Animal Behaviour Science, 73: $426 \quad 59-68$. 
427

428

429

430

431

432

433

434

435

436

437

438

439

440

441

442

443

444

445

446

448

449

450

HUGHES, B.O. \& GENTLE, M.J. (1995) Beak trimming of poultry: its implications for welfare. World's Poultry Science Journal, 51: 51-61.

JOHNSEN, P., VESTERGAARD， K.S., NORGAARD-NIELSEN， G. (1998) Influence of early rearing conditions on the development of feather pecking and cannibalism in domestic fowl. Applied Animal Behaviour Science, 60: 2541.

NEWBERRY, R.C., KEELING, L.J., ESTEVEZ, I., \& BILCIK, B. (2007) Behaviour when young as a predictor of severe feather pecking in adult laying hens: the redirected foraging hypothesis revisited. Applied Animal Behaviour Science, 107: 262-274.

NORGAARD-NIELSEN, G., VESTERGAARD, K. \& SIMONSEN, H.B. (1993) Effects of rearing experience and stimulus enrichment on feather damage in laying hens. Applied Animal Behaviour Science, 38: 345-352.

RIBER, A.B., WICHMAN, A., BRAASTAD, B.O. et al (2007) Effects of broody hens on perch use, ground pecking, feather pecking and cannibalism in domestic fowl (Gallus gallus domesticus). Applied Animal Behaviour Science, 106: $39-51$.

RODENBURG, T.B., VAN HIERDEN, Y.M., BUITENHUIS, A.J., RIEDSTRA, B., KOENE, P., VAN DER POEL, J.J., GROOTHUIS, T.G.G. \& BLOKHUIS, H.J. (2004) Feather pecking in laying hens: new insights and directions for research? Applied Animal Behaviour Science, 86: 291-298.

RODENBURG, T.B., TUYTTENS, F.A.M., DE REU, K. et al (2008)a Welfare assessment of laying hens in furnished cages and non-cage systems: an onfarm comparison. Animal Welfare, 17: 363-373. 
451

452

453

454

455

456

457

458

459

460

461

462

463

464

465

466

RODENBURG, T.B., KOMEN, H., ELLEN, E.D., UITDEHAAG, K.A. \& VAN ARENDONK, J.A.M. (2008)b. Selection method and early-life history affect behavioural development, feather pecking and cannibalism in layiung hens: a review. Applied Animal Behaviour Science, 110: 217-228.

SAVORY, C.J. (1995) Feather pecking and cannibalism. World's Poultry Science Journal. 51, 215-219.

STAACK, M., GRUBER, B., KEPPLER, C., ZALUDIK, K., NIEBUHR, K., KNIERIM, U. (2007) Importance of the rearing period for laying hens in alternative systems. Deutsche Tierarztliche Wochenschrift, 114: 86-90.

TAUSON, R. \& SVENSSON, R.A. (1980) Influence of plumage condition on the hen's feed requirements. Swedish Journal of Agricultural Research, 10: 35-39.

VAN DE WEERD, H.A. \& ELSON, A. (2006) Rearing factors that influence the propensity for injurious feather pecking in laying hens. World's Poultry Science Journal, 62: 654-664.

WEI, L.J. (1992) The accelerated failure time model - a useful alternative to the Cox regression model in survival analysis. Statistics in Medicine 11: 1871-1879. 
467

468 469

470 471 472 473 474 475 476 477 478 479 480 481

482 483 484 485 486 487 488 489 490 491

85

\section{Captions to figures.}

Figure 1. Initial bird numbers on transfer to the lay house and incidence of FP in the study houses. Each bar represents one house and points on each bar represent the final bird number at clearance. Houses on the same farm are grouped by dotted lines. Columns with an asterisk represent flocks that went on to develop FP (mean feather score of $\geq 3.8$ ) prior to 40 weeks of age.

Figure 2. Average feather damage score by age category for each house. The solid black horizontal line represents the level of feather damage regarded as 'failure' -a mean flock feather score of 3.8 or greater. Grey lines represent houses that fail before 40 weeks of age. 


\section{Tables}

Table 1. Feather damage score

\section{Score Description of body}

$0 \quad$ Well feathered body parts with no or little damage

1 Slight damage to any area of the body with feathers ruffled, body completely/almost completely covered

2 Severe damage to feathers, but localised naked area $\left(<5 \mathrm{~cm}^{2}\right)$

3 Severe damage to feathers, and large naked areas $\left(>5 \mathrm{~cm}^{2}\right)$

4 Severe damage to feathers, $>5 \mathrm{~cm}^{2}$ naked area and haemorrhage or broken skin 
Table 2. Feather damage scores (FS) in birds of different ages as predictors of the future time at which a house would reach a mean feather score of 3.8 or more.

\begin{tabular}{|l|l|l|l|l|l|}
\hline Age in & Estimated & \multicolumn{2}{|c|}{$95 \%$} & p- & Comments \\
weeks & effect & confidence interval & value & \\
\hline $15-17$ & $30.3 \%$ & $-54.3 \%$ & $271.7 \%$ & 0.62 & \\
\hline $17-20$ & $-38.2 \%$ & $-55.9 \%$ & $-13.5 \%$ & $\mathbf{0 . 0 0 5}$ & associated with 38.2\% \\
\hline $30-40$ & $-9.6 \%$ & $-16.1 \%$ & $-2.7 \%$ & $\mathbf{0 . 0 0 7}$ & reduction in time to failure \\
\hline $24-30$ & $-16.2 \%$ & $-47.3 \%$ & $33.1 \%$ & 0.45 & reduction in time to failure \\
\hline & & & & & \\
\hline
\end{tabular}


Table 3. Management systems and husbandry practices as predictors of the time at which a house would reach a mean feather score of 3.8 or more.

\begin{tabular}{|c|c|c|c|c|c|}
\hline & $\begin{array}{l}\text { Estimated } \\
\text { effect }\end{array}$ & $\begin{array}{c}95 \% \\
\text { Confidence }\end{array}$ & interval & $\begin{array}{c}\text { p- } \\
\text { value }\end{array}$ & Comments \\
\hline $\begin{array}{l}\text { Organic * } \\
(\mathrm{Y} / \mathrm{N})\end{array}$ & $-6.6 \%$ & $-18.9 \%$ & $7.4 \%$ & 0.34 & \\
\hline $\begin{array}{l}\text { Veranda } \\
(\mathrm{Y} / \mathrm{N})\end{array}$ & $-7.6 \%$ & $-19.4 \%$ & $6.0 \%$ & 0.26 & \\
\hline $\begin{array}{l}\text { Perch } \\
(\mathrm{Y} / \mathrm{N})\end{array}$ & $-7.1 \%$ & $-19.2 \%$ & $6.7 \%$ & 0.30 & \\
\hline $\begin{array}{l}\text { Feeder } * * \\
\text { (Chain/pan) }\end{array}$ & $-19.7 \%$ & $-31.9 \%$ & $-5.3 \%$ & 0.009 & $\begin{array}{l}\text { Houses with chain } \\
\text { feeders failed } 19.7 \% \\
\text { sooner than pan }\end{array}$ \\
\hline $\begin{array}{l}\text { Feeder ht } \\
(\mathrm{H} / \mathrm{L})\end{array}$ & $21.1 \%$ & $5.9 \%$ & $38.4 \%$ & 0.005 & $\begin{array}{l}\text { Houses with high } \\
\text { feeders failed } 21.1 \% \\
\text { later than low }\end{array}$ \\
\hline
\end{tabular}

*This analysis compared free-range with organic and omitted barn systems

**This analysis omitted houses that had both chain and pan $(n=3)$. 
Table 4. Daily feed intake (grams/hen/day) at different ages as a predictor of the time at which a house would reach a mean feather score of 3.8 or more.

\begin{tabular}{|c|c|c|c|c|c|}
\hline $\begin{array}{l}\text { Age } \\
\text { (weeks) }\end{array}$ & $\begin{array}{l}\text { Estimated } \\
\text { effect }\end{array}$ & $\begin{array}{c}95 \% \\
\text { Confidence }\end{array}$ & interval & $\begin{array}{l}\mathrm{p}- \\
\text { value }\end{array}$ & Comments \\
\hline $15-17$ & $-1.0 \%$ & $-1.78 \%$ & $0.0 \%$ & 0.041 & Based on very limited data \\
\hline $17-20$ & $-2.6 \%$ & $-11.7 \%$ & $7.5 \%$ & 0.60 & \\
\hline $20-24$ & $-13.4 \%$ & $-23.7 \%$ & $-1.8 \%$ & 0.025 & $\begin{array}{l}\text { Each } 20 \mathrm{~g} / \mathrm{h} / \mathrm{d} \text { increase in } \\
\text { feed associated with a } \\
13.4 \% \text { reduction in time to } \\
\text { failure }\end{array}$ \\
\hline $24-30$ & $-1.0 \%$ & $-5.6 \%$ & $3.9 \%$ & 0.67 & \\
\hline $30-40$ & $-0.6 \%$ & $-3.1 \%$ & $2.0 \%$ & 0.68 & \\
\hline
\end{tabular}


Table 5. Levels of environmental variables measured.

\begin{tabular}{|l|l|l|}
\hline & Mean (sd) & Range \\
\hline Light (lux) & $29.6(65.4)$ & $2.0-869.1$ \\
\hline Sound $(\mathrm{dB})$ & $59.4(12.7)$ & $14.3-80.0$ \\
\hline $\mathrm{CO}_{2}(\mathrm{ppm})$ & $586(327)$ & $43-2000$ \\
\hline Ammonia $(\mathrm{ppm})$ & $21.9(18.4)$ & $0-100$ \\
\hline Litter temp. $\left({ }^{\circ} \mathrm{C}\right)$ & $17.5(4.5)$ & $5.7-27.9$ \\
\hline Litter $\mathrm{pH}$ & $7.13(2.5)$ & $1.14-13.62$ \\
\hline
\end{tabular}


Table 6. Factors in rear as predictors of time at which a house reached a mean feather score of 3.8 or more.

\begin{tabular}{|c|c|c|c|c|c|}
\hline $\begin{array}{l}\text { Reared } \\
\text { with }\end{array}$ & $\begin{array}{l}\text { Estimated } \\
\text { effect }\end{array}$ & $\begin{array}{r}95 \% \\
\text { Confidence }\end{array}$ & interval & $\begin{array}{l}\mathrm{p}- \\
\text { value }\end{array}$ & Comments \\
\hline $\begin{array}{l}\text { Chain } \\
\text { feed }\end{array}$ & $-26.8 \%$ & $-41.6 \%$ & $-8.2 \%$ & 0.0068 & $\begin{array}{l}\text { Houses with chain } \\
\text { feeders in rear failed } \\
26.8 \% \text { sooner than } \\
\text { houses with both chain } \\
\text { and pan in rear }\end{array}$ \\
\hline Bell & $-15.0 \%$ & $-26.3 \%$ & $-2.0 \%$ & 0.0255 & $\begin{array}{l}\text { Houses with bell } \\
\text { drinkers in rear failed } \\
15 \% \text { sooner than } \\
\text { houses with nipple + } \\
\text { cup drinkers in rear }\end{array}$ \\
\hline Bell/nipple & $-39.6 \%$ & $-50.6 \%$ & $-26.1 \%$ & $\begin{array}{c}<0.0001 \\
8\end{array}$ & $\begin{array}{l}\text { Houses with both bell } \\
\text { and nipple drinkers in } \\
\text { rear failed } 39.5 \% \\
\text { sooner than houses } \\
\text { with nipple drinkers }\end{array}$ \\
\hline $\begin{array}{l}\text { Nipples } \\
\text { +/-cups }\end{array}$ & $-6.8 \%$ & $-23.8 \%$ & $14 \%$ & 0.49 & 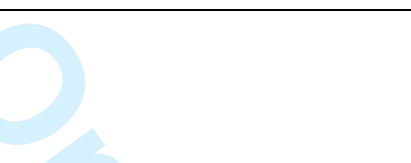 \\
\hline Light type & $29.8 \%$ & $6.9 \%$ & $57.8 \%$ & 0.0086 & $\begin{array}{l}\text { Houses with } \\
\text { fluorescent or natural } \\
\text { light in rear failed } \\
29.8 \% \text { later than } \\
\text { houses with tungsten } \\
\text { light in rear }\end{array}$ \\
\hline
\end{tabular}


Table 7. Factors that changed between rear and lay as predictors of the time that a house reached a mean feathers score of 3.8 or more.

\begin{tabular}{|c|c|c|c|c|c|}
\hline $\begin{array}{l}\text { Change } \\
\text { in }\end{array}$ & $\begin{array}{l}\text { Estimated } \\
\text { effect }\end{array}$ & $\begin{array}{r}95 \% \\
\text { Confidence }\end{array}$ & interval & $\begin{array}{l}\mathrm{p}- \\
\text { value }\end{array}$ & Comments \\
\hline $\begin{array}{l}\text { Veranda } \\
\text { in rear } \\
\text { Y/N }\end{array}$ & $9.4 \%$ & $-4.5 \%$ & $255.4 \%$ & 0.19 & \\
\hline $\begin{array}{l}\text { Perch } \\
\mathrm{Y} / \mathrm{N}\end{array}$ & $6.7 \%$ & $-6.3 \%$ & $21.7 \%$ & 0.33 & \\
\hline $\begin{array}{l}\text { Feeder } \\
\text { type Y/N }\end{array}$ & $-19.2 \%$ & $-28.5 \%$ & $-8.7 \%$ & 8 & $\begin{array}{l}\text { Houses which had the } \\
\text { same feeder type in rear } \\
\text { and lay failed } 19.2 \% \\
\text { sooner than houses of } \\
\text { birds which experienced a } \\
\text { change in feeder type } \\
\text { from rear to lay. }\end{array}$ \\
\hline $\begin{array}{l}\text { Drinker } \\
\text { type Y/N }\end{array}$ & $-10.1 \%$ & $-22.3 \%$ & $-4.1 \%$ & 0.15 & \\
\hline $\begin{array}{l}\text { Light } \\
\text { type Y/N }\end{array}$ & $10.1 \%$ & $-5.1 \%$ & $27.6 \%$ & 0.20 & \\
\hline $\begin{array}{l}\text { Farm } \\
\mathrm{Y} / \mathrm{N}\end{array}$ & $28.4 \%$ & $6.1 \%$ & $55.5 \%$ & 0.010 & $\begin{array}{l}\text { Houses of birds reared on } \\
\text { the same farm as lay } \\
\text { failed } 28.4 \% \text { later than } \\
\text { houses of birds reared on } \\
\text { different farm. }\end{array}$ \\
\hline Sum & $-1.7 \%$ & $-8.1 \%$ & $5.2 \%$ & 0.62 & \\
\hline
\end{tabular}


Figure 1.

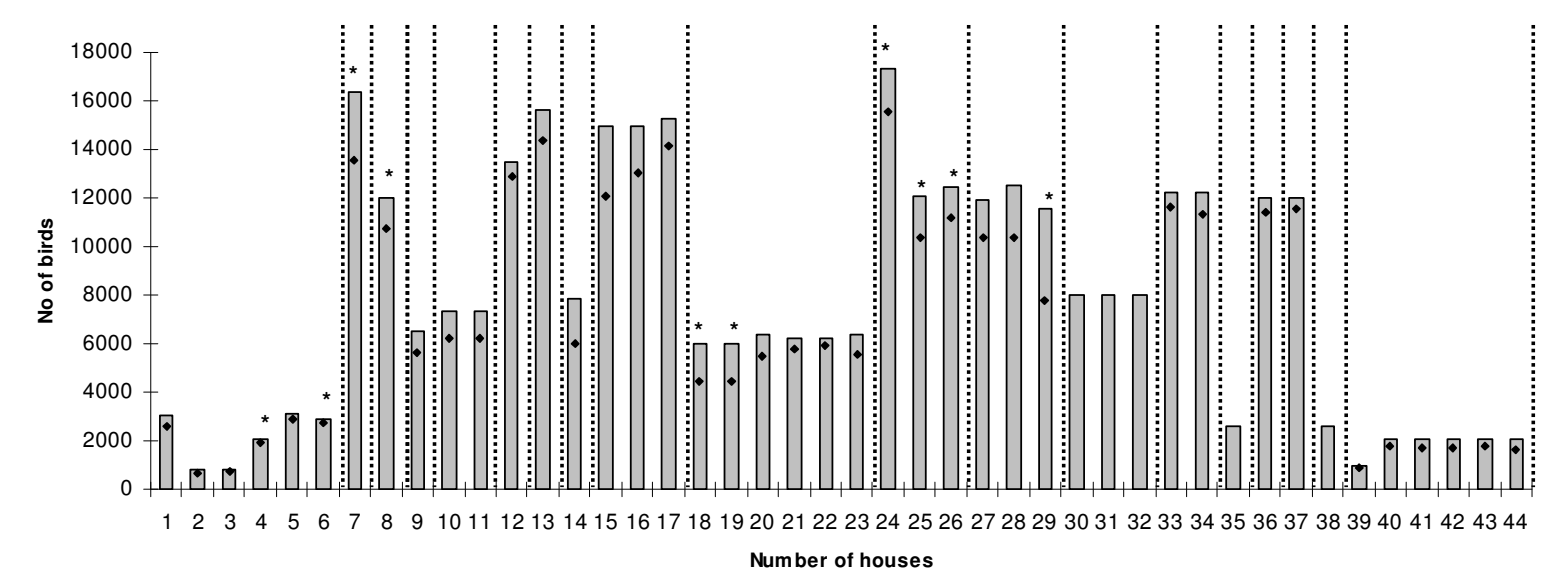


Figure 2.

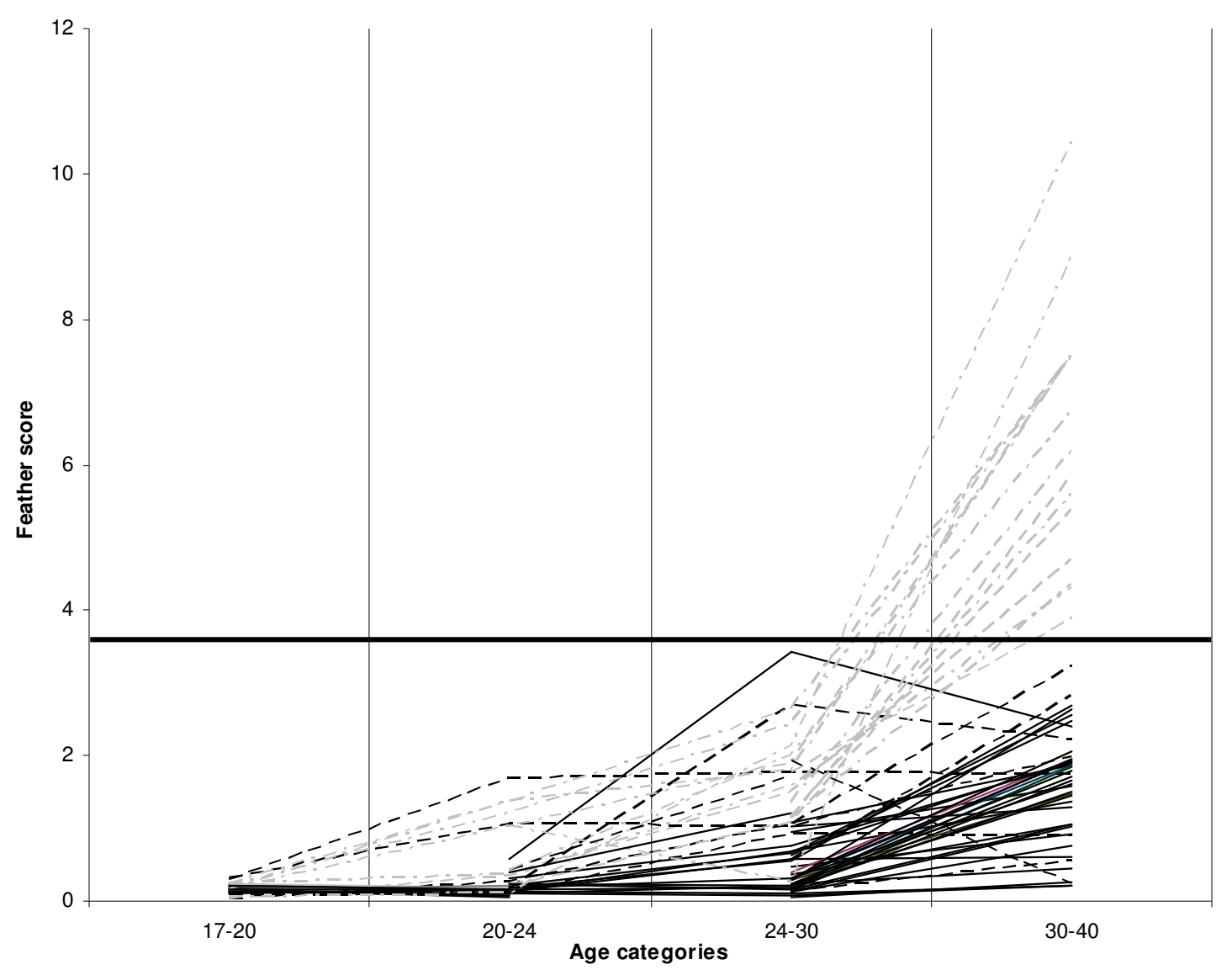

1

3

5

6

7

9

10

11

12

13

14

15

16

17

18

19
20

21

22

23

24

25

26

27

28

29

30

31

32

33

34

35

36

37

38

39

40

41

42

43

44

45

46

47

48

49

50

51

52

53

54

55

56

57

58

59

60 